\title{
ASSOCIATION OF ENAM C2452T POLYMORPHISM WITH HIGH RATES OF CARIES OCCURRENCE IN AN INDONESIAN POPULATION
}

\section{NICOLINE NICOLINE ${ }^{1}$, FATIMAH BOENJAMIN PARTAKUSUMA ${ }^{2}$, HEDIJANTI JOENOES ${ }^{1}$, CHRISTOPHER TALBOT $^{3}$, ELZA IBRAHIM AUERKARI ${ }^{1 *}$}

${ }^{1}$ Department of Oral Biology, Faculty of Dentistry, Universitas Indonesia, Jakarta, Indonesia. ${ }^{2}$ Department of Pediatric Dentistry, Faculty of Dentistry, Universitas Trisakti, Jakarta, Indonesia. ${ }^{3}$ Department of Genetics, University of Leicester, Leicester, UK. Email: eiauerkari@yahoo.com

Received: 02 October 2019, Revised and Accepted: 24 December 2019

ABSTRACT

Objective: Tooth decay or the caries process is a common dental problem that affects millions of people worldwide. Many risk factors are modifiable, while others are not (e.g., genetic factors). Polymorphism of the enamelin (ENAM) gene, which is required to ensure production of an essential protein for enamel development, may pose as a risk factor for the caries process. This study sought to investigate the possibility of ENAM C2452T polymorphism acting as a risk factor in the caries process.

Methods: The polymerase chain reaction-restriction fragment length polymorphism method was employed to evaluate DNA samples taken from 95 subjects with a high caries prevalence and 89 control subjects for ENAM C2452T polymorphism.

Results: Based on Chi-squared tests, there were significant genotype and allele distribution differences between the group with a high caries prevalence and the control group ( $\mathrm{p}=0.005$ and $\mathrm{p}=0.007$ ). Polymorphism in this context may, therefore, serve as a risk factor for caries onset and progression (OR: 3.62).

Conclusion: ENAM C2452T polymorphism is related to the caries process and may constitute a risk factor.

Keywords: Caries, Enamelin, Polymorphism, Indonesia.

(c) 2020 The Authors. Published by Innovare Academic Sciences Pvt Ltd. This is an open access article under the CC BY license (http://creativecommons. org/licenses/by/4. 0/) DOI: http://dx.doi.org/10.22159/ijap.2020.v12s1.14228

\section{INTRODUCTION}

According to the United States (US) National Institute of Dental and Craniofacial Research, roughly $92 \%$ of adults aged 20-64 years show tooth decay on their permanent teeth [1]. Further, among this population, $26 \%$ do not receive regular dental care. In Indonesia, approximately 65 million residents have dental problems including tooth decay, with only $31 \%$ receiving dental care [2].

Tooth decay or dental caries is a dynamic process that affects the outer layers of the tooth when the demineralization and remineralization processes are not balanced with one another $[3,4]$. The caries process is initiated by dental plaque or biofilm, made up of a community of microorganisms that adhere to the dental surfaces and which can demonstrate cariogenic properties if left untreated. Microorganisms can be characterized as cariogenic if they produce polysaccharides, convert sugar to fatty acids (acidogenic), or tolerate a highly acidic environment (aciduric). Cariogenic microorganisms act to disrupt the regular remineralization-demineralization process, as they promote an increase in the demineralization side of the process [4]. Caries itself can be categorized as either occurring at a high rate or a low rate using the decayed-missing-filled (DMFT) index (for permanent teeth) or decayed-extracted-filled teeth (def-t) index (for deciduous teeth). Both indices consider the presence of decayed, missing, and filled teeth, with a score of 10 points for DMFT or 4.5 points for def-t being the cutoff values for high caries occurrence versus low occurrence [5].

There are currently several known risk factors that contribute to caries onset and progression. However, among these, certain risk factors (e.g., age and genetic factors) cannot be changed. According to a recent study, individuals boasting genetic polymorphism of certain genes such as enamelin (ENAM), mannose-binding lectin-2, and amelogenin $X$ are more prone to experiencing this process $[2,6,7]$. Genetic polymorphism can be described as gene sequence variations between individuals that may or may not affect one's health. A genetic variation is considered a polymorphism when it affects a specific allele in more than $1 \%$ of a population group [8]. Single-nucleotide polymorphisms (SNPs) are the most common kind of genetic polymorphism, where a specific nucleotide base changes into another, affecting one in every 300 nucleotide bases and which may act as a biological marker for certain health concerns. While most SNPs do not have any discernible effects on health, some have been proven to be associated with certain diseases [9].

The ENAM gene, located on the q arm of the fourth chromosome on 13.3 (4q13.3), provides instructions for constructing ENAM proteins that are required in normal tooth development, especially including the formation of the enamel, the outermost layer of a tooth structure. Until now, its specific behavior has not been fully recognized [10]. Several polymorphisms of this gene have been suggested previously to be associated with the caries process $[6,7,11-14]$.

\section{MATERIALS AND METHODS}

Study subjects and ethical approval

This study used 184 DNA samples extracted from consenting patients' peripheral blood, with the study population consisting of 95 individuals with high caries occurrence (study group) and 89 individuals with low or no caries occurrence (control group). The extracted DNA samples were stored in the Oral Biology Laboratory, Faculty of Dentistry, Universitas Indonesia, at $-20^{\circ} \mathrm{C}$. This study and its methods were approved by the Universitas Indonesia, Faculty of Dentistry's Ethical Committee (Number: 92/Ethical Approval/FKGUI/VI/2017). 
DNA isolation and genotyping

To identify ENAM C2452T polymorphism, we performed DNA isolation as described by Auerkari et al. [15-17] and genotyping procedures as described by Ouryouji et al. [14]. Each 20 - $\mu \mathrm{L}$ polymerase chain reaction (PCR) mixture contained $10 \mu \mathrm{L}$ of ready-to-use master mix (Bioline, London, UK), $0.4 \mu \mathrm{L}$ of forward (5'-AGG ATT TTT ATT ACA GTG AAT TTT ACC CAT GGG GCC-3') and reverse primers (3'-CCT TAA GGA CCC TGG TGT CCT ATG TTC-5'), and $20 \mu \mathrm{g}$ of genomic DNA

PCR was performed in a $\mathrm{T} 100^{\mathrm{TM}}$ thermal cycler (Bio-Rad Laboratories, Hercules, CA, USA) with the following temperature profiles: Initial denaturation at $96^{\circ} \mathrm{C}$ for $2 \mathrm{~min}$, followed by 37 cycles of denaturation at $94^{\circ} \mathrm{C}$ for $1 \mathrm{~min}$, annealing at $58.2^{\circ} \mathrm{C}$ for $1.5 \mathrm{~min}$, and extensions at $72^{\circ} \mathrm{C}$ for $1 \mathrm{~min}$, with a final extension occurring at $74^{\circ} \mathrm{C}$ for $7 \mathrm{~min}$.

The PCR products were then digested with one unit of ApaI restriction enzyme (Genetika Science, Indonesia) for $20 \mathrm{~min}$ at $25^{\circ} \mathrm{C}$. Next, the digested products were separated in $2 \%$ agarose gel stained with GelRed (Biotium Inc., Hayward, CA, USA) and recorded with Gel Doc 200 (Bio-Rad Laboratories, Hercules, CA, USA).

Apa I digestion yielded fragments of $36 \mathrm{bp}$ and $144 \mathrm{bp}$ (homozygote G/G); $36 \mathrm{bp}, 144 \mathrm{bp}$, and $180 \mathrm{bp}$ (heterozygote G/A); and $180 \mathrm{bp}$ (homozygote $G / G$ ), respectively.

\section{Statistical analysis}

Genetic data were entered and processed using the Statistical Package for the Social Sciences (SPSS) version 22.0 software program (IBM Corp., Armonk, NY, USA) and examined using a descriptive analysis approach. Associations between high caries incidence and ENAM genotype were evaluated with the Chi-squared test and binary logistic regression analysis.

\section{RESULTS}

This study involved 96 samples DNA of individuals with high caries occurrence and 89 samples of DNA of individuals with low caries occurrence (Table 1). Amplified PCR products were confirmed as ENAM C2452T by electrophoresis as shown in Figs. 1-3. Fig. 1 also presents examples of digested PCR products, where the CT genotype (sample no. 4) was indicated by two bands of $180 \mathrm{bp}$ and $144 \mathrm{bp}$; sample no. 5 and 6 showed a single band of $144 \mathrm{bp}$, representing the CC genotype; and sample no. 7 showed a single band of $180 \mathrm{bp}$, representing the TT genotype. No instance of a 36-bp band was seen as such is located within the primer and was not able to be discriminated by electrophoresis.

The results of PCR-restriction fragment length polymorphism (RFLP) evaluation of ENAM C2452T revealed that genotype CC and allele C were dominant in the general population. A total of 151 samples carried the wild-type homozygote $\mathrm{C} / \mathrm{C}, 23$ samples carried the polymorphic heterozygote $\mathrm{C} / \mathrm{T}$, and 10 samples carried the polymorphic homozygote T/T (Table 2). Among 368 alleles from 184 samples, only 43 demonstrated polymorphic alleles. Moreover, Table 3 describes a comparison of the distribution of ENAM C2452T polymorphism between Indonesian, Japanese, and Polish patients with high caries occurrence and low caries occurrence.

\section{DISCUSSION}

As a tooth-specific protein matrix, ENAM is produced by the ENAM gene. This protein matrix is secreted in an ameloblast secretory stage and is a necessary element in the enamel mineralization phase $[11,14]$.

Research indicates a nucleic acid base change or SNPs of this gene can result in hereditary enamel hypoplasia and may alter individual enamel thickness as well as the teeth's magnesium and calcium concentrations, impacting the demineralization process and resulting in a progression of the caries process [7].
Table 1: Number of study subjects

\begin{tabular}{lll}
\hline & Frequency & Percentage \\
\hline High caries occurrence group & 89 & 48.37 \\
Control group & 95 & 51.63 \\
Total & 184 & 100 \\
\hline
\end{tabular}

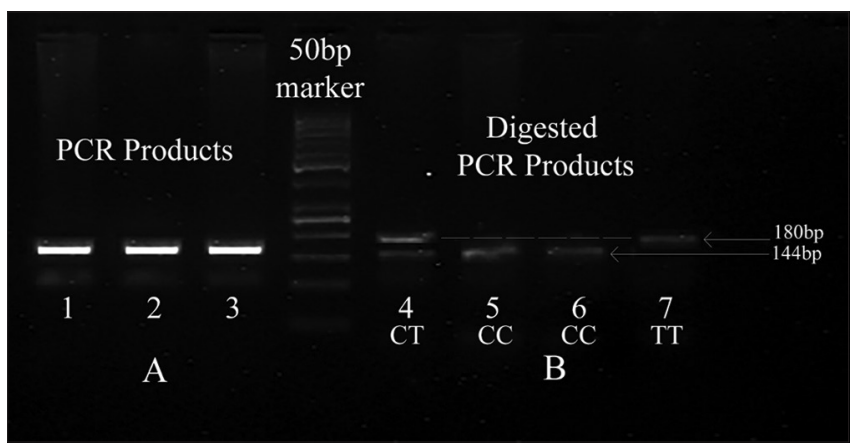

Fig. 1: Visualization of PCR conducted for DNA isolation and associated digested PCR products. Lanes 1 through 3 represent the PCR products with 144-bp bands, while lanes 4 through 7 represent the digested PCR products. Lane 4 shows both 180-bp and 144-bp bands, lanes 5 and 6 show only a 144-bp band, and lane 7 shows only a 180-bp band. No 36-bp band was observed as such is located within the primer and was not able to be discriminated by electrophoresis

The present study sought to identify the difference in the distribution of ENAM C2452T polymorphism among individuals with high caries activity and low caries activity in an Indonesian population. According to the US National Institute of Dental and Craniofacial Research, nine of 10 adults aged 20-64 years old have at least one active caries lesion on their permanent teeth [1]. In Indonesia, 65 million individuals have dental problems including caries [2].

Gene polymorphism changes the sequence of various genes including $E N A M$, which can lead either to no health effect or to susceptibility to certain conditions or diseases such as a vulnerability to the caries process. The polymorphism of the ENAM gene is also proven to be related with one type of amelogenesis imperfecta, a disorder of tooth development that results in teeth that appear discolored, pitted or grooved, unusually small, and inclined to wear and breakage, which is essentially an example of hypoplasia $[14,18]$. Thereby, a change in the nucleic acid base of this gene may adversely affect the capacity of the enamel structure.

In a previous study that focused on the influence of ENAM C2452T polymorphism on the caries process by comparing individuals with high caries occurrence and low caries occurrence across various races, a significant difference was not reported. However, the conversion of the cytosine base (C) to thymine base (T) in the +2452 position in the present research had a different outcome than that of this prior study. This difference is likely a result of genetic variations between races.

To visualize the genotype of the gene for each DNA sample, amplification was performed on the specific gene position using PCR through denaturation, annealing, and elongation phases. Following successful amplification, all amplified DNA samples were digested with ApaI restriction enzyme by way of an RFLP technique. Restricted or digested products then were visualized with GelDoc. The visualization results were subsequently analyzed using the SPSS software program and showed that genotype and allele distribution differences were present between individuals with high caries occurrence and low caries occurrence, respectively. These findings may indicate that certain genetic factors have an affinity toward caries occurrence. 


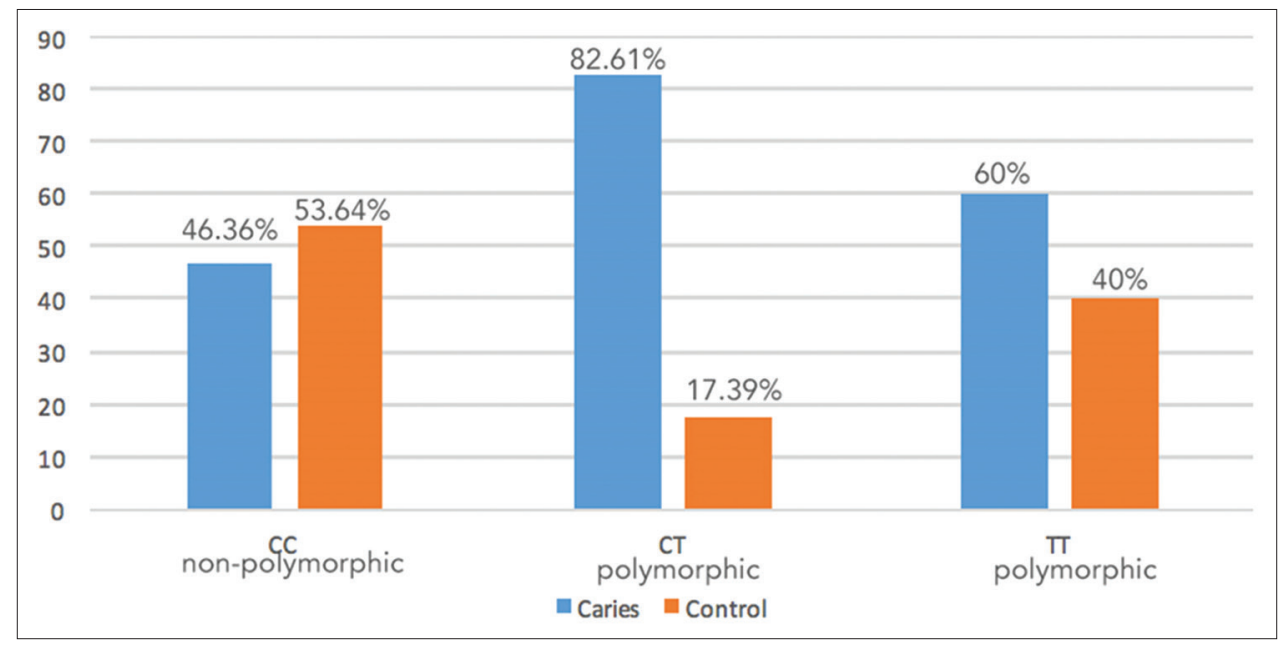

Fig. 2: ENAM C2452T polymorphism genotype distribution

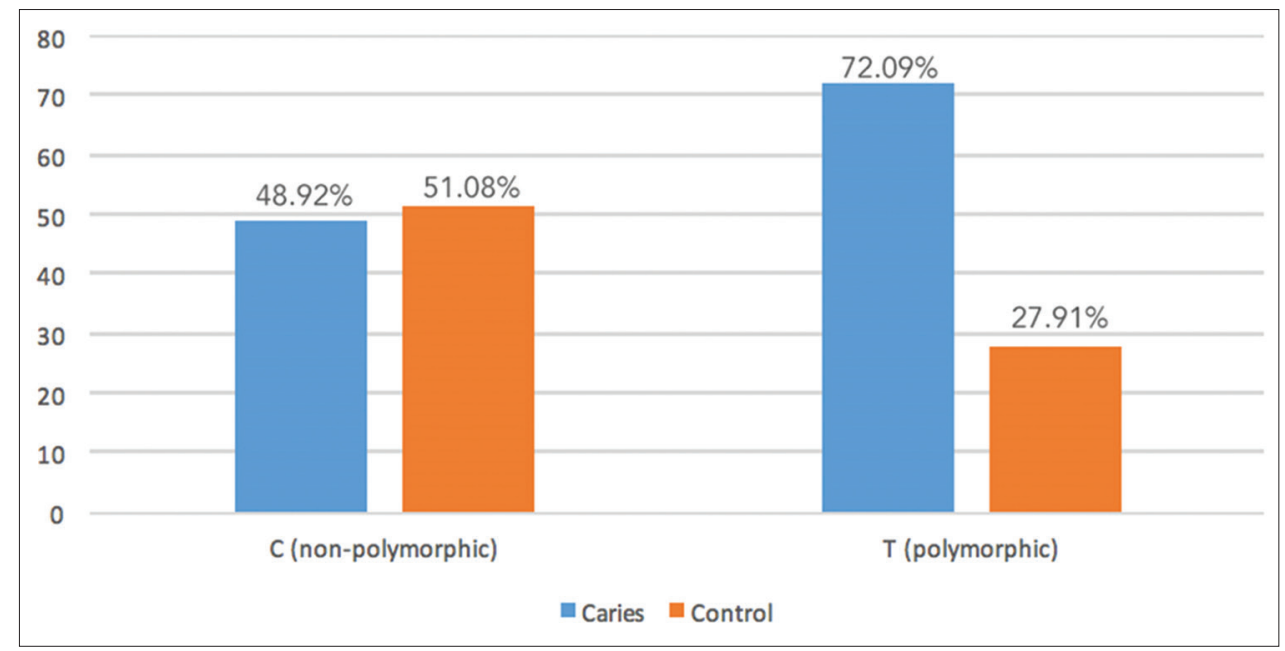

Fig. 3: ENAM C2452T polymorphism allele distribution

Table 2: Genotype frequency among individuals with high caries occurrence versus control subjects

\begin{tabular}{llll}
\hline Polymorphism & $\begin{array}{l}\text { High caries (DMFT } \geq \mathbf{1 0} \text { points or } \\
\text { def-t } \mathbf{4} \text {.5 points) }\end{array}$ & $\begin{array}{l}\text { Control (DMFT<10 points or } \\
\text { def-t<4.5 points) }\end{array}$ & Pearson's Chi-squared test \\
\hline Enamelin C2452T & & & \\
CC & $70(46.36 \%)$ & $81(53.64 \%)$ & $\mathrm{p}=0.005$ \\
CT & $19(82.61 \%)$ & $4(17.39 \%)$ & \\
TT & $6(60 \%)$ & $4(40 \%)$ & $\mathrm{p}=0.007$ \\
C & $159(48.92 \%)$ & $166(51.08 \%)$ & \\
T & $31(72.09 \%)$ & $12(27.91 \%)$ & \\
\hline
\end{tabular}

Ouryouji et al. in 2008 reported that there was no statistically significant difference between ENAM C2452T polymorphism and high caries occurrence in a Japanese population ( $\mathrm{p}=0.143$ and $\mathrm{p}>0.05$ ). Their study, which included 57 individuals as control subjects (individuals with low caries occurrence or DMFT $<10$ points/def- $\mathrm{t}<4.5$ points) and 80 individuals as caries subjects (individuals with high caries occurrence or DMFT $\geq 10$ points/def- $t \geq 4.5$ points) stated that CC genotype (wildtype or nonpolymorphic) dominated among both control (88.1\%) and caries $(96 \%)$ subjects [14].

Another study, conducted by Olszowski et al. in 2012, also reported that no statistically significant difference was present between ENAM C2452T polymorphism and high caries occurrence in a Polish population $(\mathrm{p}=0.67, \mathrm{p}=0.18$, and $\mathrm{p}>0.05$ ). Their research included 84 individuals as control subjects (individuals with low caries occurrence or DMFT
$<10$ points/def- $t<4.5$ points) and 95 individuals as caries subjects (individuals with high caries occurrence or DMFT $\geq 10$ points/def-t $\geq 4.5$ points) and stated that the $\mathrm{C}$ allele (wild-type or nonpolymorphic) dominated in both study populations $(73.16 \%$ of caries subjects and $77.38 \%$ of control subjects) [6].

In contrast, this research, which focused on synonymous polymorphism, reported a different outcome. Among 95 caries subjects (individuals with high caries occurrence or DMFT $\geq 10$ points/def-t $\geq 4.5$ points), it was found that 25 individuals $(26.3 \%)$ presented a mutant-type or polymorphic genotype (CT or TT genotype), while eight individuals (9\%) among 89 control subjects (individuals with low caries occurrence or DMFT $<10$ points/def-t $<4.5$ points) displayed a mutant-type or polymorphic genotype (CT or TT genotype). 
Table 3: Comparison of the distribution of ENAM C2452T polymorphism between Indonesian, Japanese, and Polish patients with high caries occurrence and low caries occurrence

\begin{tabular}{|c|c|c|c|}
\hline Study & Population & Caries (genotype/allele) (\%) & Control (genotype/allele) (\%) \\
\hline \multirow[t]{5}{*}{ Present study } & Indonesian & CC (46.36) & CC (53.64) \\
\hline & & CT (82.61) & CT (17.39) \\
\hline & & $\mathrm{TT}(60)$ & $\mathrm{TT}(40)$ \\
\hline & & $\mathrm{C}$ allele (48.92) & $\mathrm{C}$ allele (51.08) \\
\hline & & T allele (72.09) & $\mathrm{T}$ allele (27.91) \\
\hline \multirow[t]{5}{*}{ Ouryouji et al. (2008) [14] } & Japanese & CC $(48.12)$ & CC (51.88) \\
\hline & & CT (70.41) & CT (29.59) \\
\hline & & $\mathrm{TT}(0)$ & $\mathrm{TT}(0)$ \\
\hline & & $\mathrm{C}$ allele (52.03) & $\mathrm{C}$ allele (47.97) \\
\hline & & $\mathrm{T}$ allele (31.04) & $\mathrm{T}$ allele (68.96) \\
\hline \multirow[t]{2}{*}{ Olszowski et al. (2012) [6] } & Polish & $\mathrm{C}$ allele (50.93) & $\mathrm{C}$ allele (49.07) \\
\hline & & $\mathrm{T}$ allele (46.07) & $\mathrm{T}$ allele (53.93) \\
\hline
\end{tabular}

Despite the fact that both a wild-type or nonpolymorphic allele (C) and genotype (CC) were found more often than the mutant-type or polymorphic allele (T) and genotype (CT or TT) in both subject groups, a continuity correction calculation revealed that there was a statistically significant difference between the distribution of wild-type or nonpolymorphic alleles and mutant-type or polymorphic alleles with $p=0.007(p<0.05)$. Further, the continuity correction calculation of the genotype showed $\mathrm{p}=0.005(\mathrm{p}<0.05)$, which means that there is a statistically significant difference between the distribution of the wildtype or nonpolymorphic genotype and mutant-type or polymorphic genotype. The Hardy-Weinberg equilibrium analysis result for this research was 28.61, which means that the genotype distribution in this research followed the Hardy-Weinberg equilibrium theorem, whereas the genotype and allele polymorphism distribution among the broader Indonesian population is likely to constant generation to generation.

\section{CONCLUSION}

This study found that ENAM C2452T polymorphism might represent a risk factor for the caries process. However, more substantial and welldesigned studies in the future with larger population samples and which consider other correlating risk factors are still needed to further explore the role of ENAM gene polymorphism in the caries process.

\section{ACKNOWLEDGMENTS}

Financial support from the Directorate of Researches and Public Services University of Indonesia is gratefully acknowledged.

\section{CONFLICTS OF INTEREST}

The author has no conflicts of interest to declare.

\section{REFERENCES}

1. National Institute of Dental and Craniofacial Research (NIH). Dental Caries (Tooth Decay) in Adults (Age 20 to 64); 2018. Available from: https://www.nidcr.nih.gov/research/data-statistics/dental-caries/adults.

2. Auerkari E, Soufyan A, Dian E, Sumariningsih P, Sarita D, Sumawinata $\mathrm{N}$, et al. Effect of xylitol on remineralization of demineralized dental enamel effect of xylitol on remineralization of demineralized dental enamel. Int J Clin Prev Dent 2010;6:73-7.

3. Featherstone JD. Dental caries: A dynamic disease process. Aust Dent J 2008;53:286-91.

4. Kidd EA, Bechal SJ. Essentials of Dental Caries. New York: Oxford University Press; 2005.
5. World Health Organization. Oral Health Surveys: Basic Methods. $5^{\text {th }}$ ed. Geneva: World Health Organization; 2013.

6. Olszowski T, Adler G, Janiszewska-Olszowska J, Safranow K, Kaczmarczyk M. MBL2, MASP2, AMELX, and ENAM gene polymorphisms and dental caries in Polish children. Oral Dis 2012;18:389-95.

7. Wang M, Qin M, Xia B. The association of enamelin, lactoferrin, and tumour necrosis factor alpha gene polymorphisms with high caries susceptibility in Chinese children under 4 years old. Arch Oral Biol 2017;80:75-81.

8. Karki R, Pandya D, Elston RC, Ferlini C. Defining "mutation" and "polymorphism" in the era of personal genomics. BMC Med Genomics 2015;8:37.

9. National Institutes of Health: Genetics Home Reference; 2016. Available from: https://www.ghr.nlm.nih.gov/gene. [Last accessed on 2019 Oct 10].

10. National Institutes of Health: Genetics Home Reference, ENAM Gene; 2017. Available from: https://www.ghr.nlm.nih.gov/gene. [Last accessed on 2019 Oct 15].

11. Gerreth K, Zaorska K, Zabel M, Borysewicz-Lewicka M, Nowicki M. Association of ENAM gene single nucleotide polymorphisms with dental caries in Polish children. Clin Oral Investig 2016;20:631-6.

12. Antunes LA, Antunes LS, Küchler EC, Lopes LB, Moura A, BigonhaRS, et al. Analysis of the association between polymorphisms in MMP2, MMP3, MMP9, MMP20, TIMP1, and TIMP2 genes with white spot lesions and early childhood caries. Int J Paediatr Dent 2016;26:310-9.

13. Bayram M, Deeley K, Reis MF, Trombetta VM, Ruff TD, Sencak RC, et al. Genetic influences on dental enamel that impact caries differ between the primary and permanent dentitions. Eur J Oral Sci 2015;123:327-34.

14. Ouryouji K, Imamura Y, Fujigaki Y, Oomori Y, Yanagisawa S, Miyazawa $\mathrm{H}$, et al. Analysis of mutations in the amelogenin and the enamelin genes in severe caries in Japanese pediatric patients. Pediatr Dent J 2008; 18:79-85.

15. Auerkari E, Suhartono A, Djamal N, Verisqa F, Suryandari D, Kusdhany L, et al. CRP and IL-1B gene polymorphisms and CRP in blood in periodontal disease. Open Dent J 2013;7:88-93.

16. Auerkari EI, Suryandari DA, Umami SS, Kusdhany LS, Siregar TW, Rahardjo TB, et al. Gene promoter polymorphism of RUNX2 and risk of osteoporosis in postmenopausal Indonesian women. SAGE Open Med 2014;2:2050312114531571.

17. Auerkari E, Savitri I, Masulili SL, Suhartono AW. Polymorphism of osteoprotegerin gene in Indonesian men with periodontitis. Int J Appl Pharm 2019;11:207-9.

18. National Institutes of Health: Genetics Home Reference, Amelogenesis Imperfecta; 2017. Available from: https:/www.ghr.nlm.nih.gov/ condition/amelogenesis-imperfecta. [Last accessed on 2019 Oct 20]. 